\title{
Different patterns of stent endothelialization and restenosis at follow-up. Optical coherence tomography observations
}

Rodzaje endotelializacji stentu i restenozy w obserwacji odległej przy użyciu optycznej tomografii koherentnej

\author{
Paweł Tyczyński', Giuseppe Ferrante ${ }^{2}$, Anna B. Witkowska', Alistair C. Lindsay', Nicolas Foin ${ }^{3}$, Liviu Ghilencea', \\ Nicola Viceconte ${ }^{1}$, Michael Chan ${ }^{1}$, Carlo Di Mario ${ }^{1}$ \\ ${ }^{1}$ The Royal Brompton Hospital, London, United Kingdom \\ 2Department of Interventional Cardiology, Istituto Clinico Humanitas IRCCS Rozzano, Milan, Italy \\ 3Imperial College, London, United Kingdom
}

Post Kardiol Interw 2011; 7, 3 (25): 248-251 DOI: $10.5114 /$ pwki.2011.24743

Key words: restenosis, optical coherence tomography

Stowa kluczowe: restenoza, optyczna tomografia koherentna

\section{Introduction}

In-stent restenosis (ISR), although infrequent in the era of drug-eluting stents (DES), remains an Achilles' heel of the percutaneous treatment of coronary artery lesions.

The new imaging modality optical coherence tomography (OCT) offers an interesting insight into the different patterns of this phenomenon.

As suggested by Gonzalo et al., the OCT appearance of restenotic tissue may be related to various factors such as clinical presentation, time from stent implantation, stent type, etc [1]. Still, the correlation between OCT appearance and the histopathological findings is not fully understood and warrants further investigation.

In the observation by Suzuki et al., the intravascular ultrasonography appearance of ISR components in native coronary arteries varied from echolucent to echodense images. Corresponding histology not only revealed smooth muscle cell proliferation, but also demonstrated delayed healing features such as organized fibrin deposition, macrophage and T-lymphocyte infiltration [2].

We present OCT images strongly suggesting different restenosis patterns among stent types, location of the lesion and various components within the same restenotic tissue resulting in distinct optical properties (figs 1-5).

\section{Discussion}

Neointimal stent strut coverage eliminates direct contact between pro-thrombotic stent material and the blood stream. Heterogeneous OCT appearance of neointimal tissue can be observed around struts in some DES, suggesting the presence of fibrin deposition and incomplete healing, possibly caused by the anti-proliferative drugs and polymer coating. 


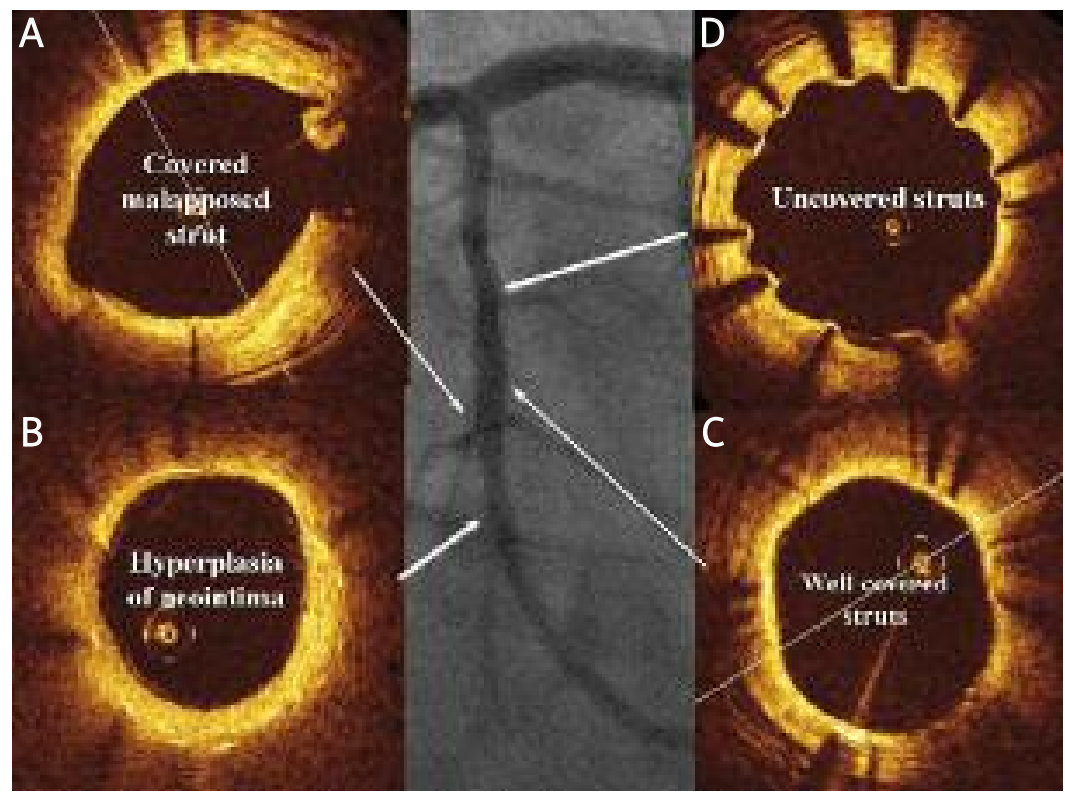

Fig. 1. Nine-month follow-up after implantation of biolimus-eluting stent into the left circumflex artery. Optical coherence tomography shows different neo-endothelialization patterns within the same artery (A-D). Bright homogeneous appearance of neointimal tissue suggesting smooth muscle cell proliferation and complete healing Ryc. 1. Obserwacja 9-miesięczna po wszczepieniu stentu uwalniającego biolimus do gatęzi okalającej. Optyczna tomografia koherentna uwidacznia różne typy endotelializacji wewnątrz tej samej tętnicy (A-D). Jasny, homogenny cień neointimy sugeruje proliferację mięśni gładkich oraz zupetne pokrycie rozpórek stentu

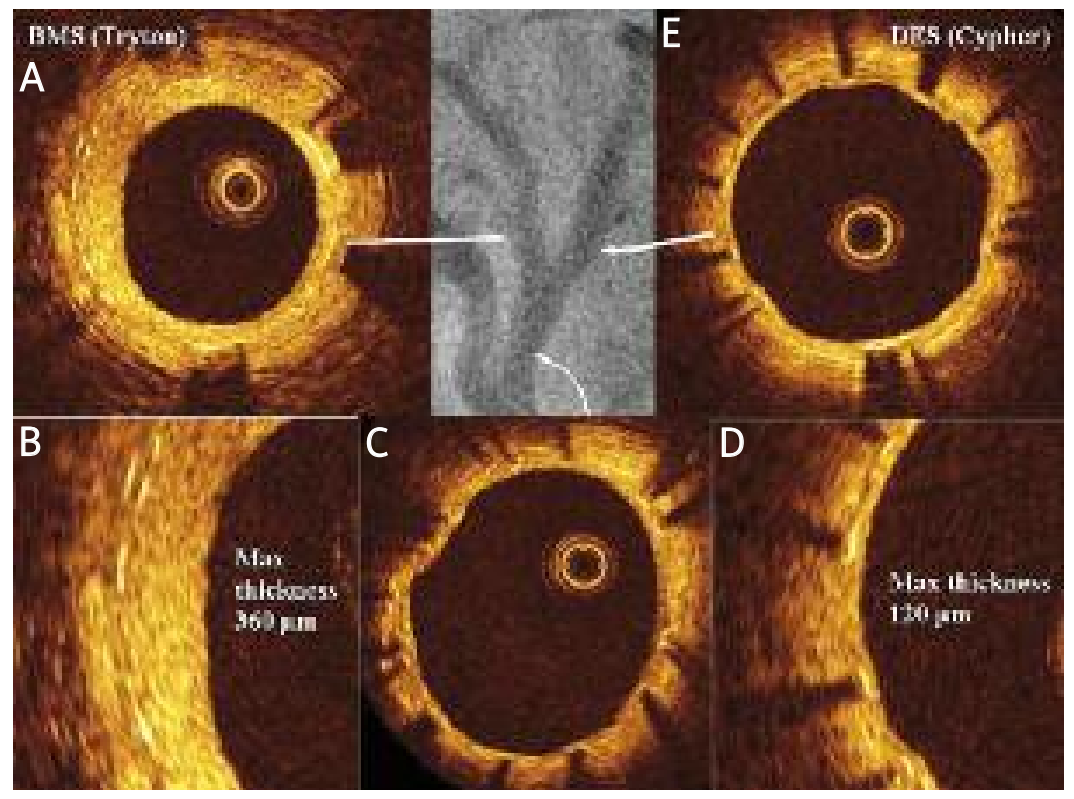

Fig. 2. Nine-month follow-up after treatment of diagonal artery and its branch - Culotte's technique. Optical coherence tomography depicts differences in the maximal thickness between neointimal coverage of bare metal stent Tryton (A) and Sirolimus-eluting stent Cypher (E). B - magnification of image 'A'. C - Proximal segment of the diagonal artery with two layers of struts. D - Magnification of image 'E'

Ryc. 2. Obserwacja 9-miesięczna po przezskórnej angioplastyce gałęzi diagonalnej i gatęzi bocznej odchodzącej od niej przy użyciu techniki Culotte. Optyczna tomografia koherentna uwidacznia różnice pomiędzy maksymalna grubościa neointimy pokrywająca stent metalowy typu Tryton (A) i stent uwalniający sirolimus - Cypher (E). $B$ - powiększenie obrazu 'A'. C - segment proksymalny gatęzi diagonalnej z dwiema warstwami rozpórek. $D$ - powiększenie obrazu ' $E$ ' 


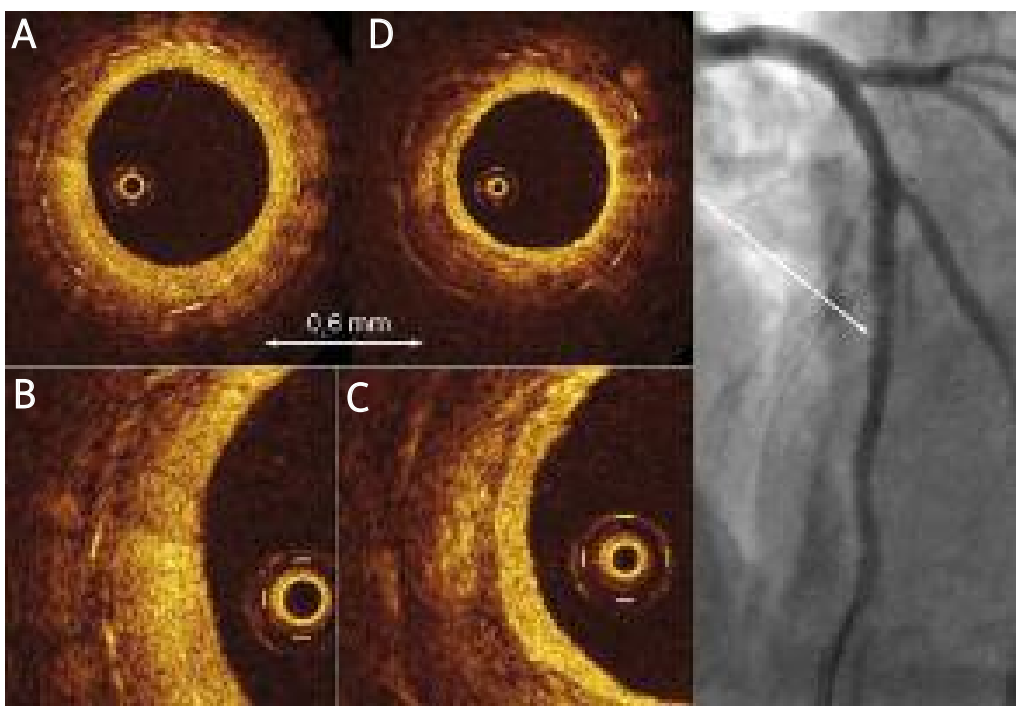

Fig. 3. Five-year follow-up after implantation of paclitaxel-eluting stent Taxus into the left anterior descending artery for non-ST segment elevation myocardial infarction. Optical coherence tomography images show different coverage patterns in segments separated by only 4 frames $(0.6 \mathrm{~mm})$. A - homogeneous bright backscatter. $D$ - two, partially sharply delineated tissue layers. B, C - magnification of images ' $A$ ' and ' $D$ ' respectively. Such heterogeneous dim appearance around struts has been suggested to be an indication of delayed healing with large fibrin deposition and presence of inflammatory cells

Ryc. 3. Obserwacja 5-letnia po wszczepieniu stentu uwalniającego paklitaksel - Taxus, do gałęzi międzykomorowej przedniej w trakcie ostrego zespołu wieńcowego bez uniesienia odcinka ST (NSTEMI). Optyczna tomografia koherentna uwidacznia różne typy pokrycia stentu w segmentach oddalonych od siebie jedynie o 4 klatki $(0,6 \mathrm{~mm})$. A - homogenne, jasne odbicie. D-dwie warstwy tkanki, częściowo wyraźnie się różniące. $B, C$ - powiększenie obrazów 'A' i 'D', odpowiednio. Uważa się, że taki heterogenny, ciemny obraz wokót rozpórek może odpowiadać opóźnionemu gojeniu się z obecnością dużych złogów fibryny i komórek zapalnych

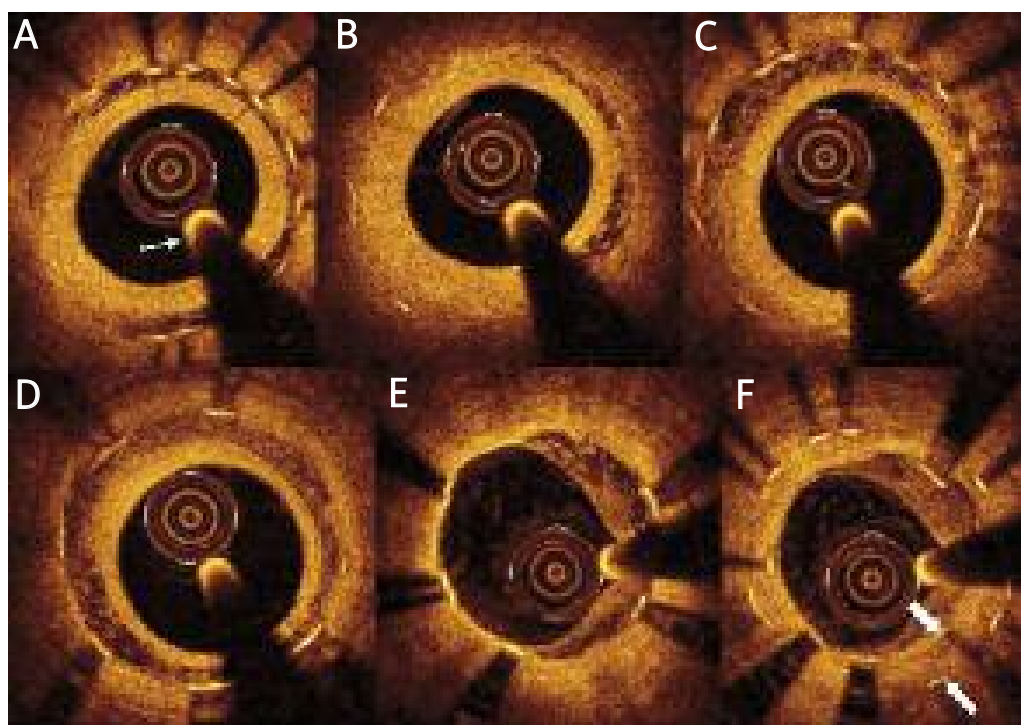

Fig. 4. Six-month follow-up after implantation of everolimus-eluting stent Promus Element into the saphenous vein graft to the right coronary artery for the treatment of restenosis in bare metal stent Duet. Optical coherence tomography shows two, mostly concentric (A-D) or eccentric (E), strongly delineated layers of the restenotic tissue. Additionally, differences are also seen between the neo-intimal tissue covering the first stent (bare metal stent) and the second (everolimus-eluting stent) (Arrowheads) (F). Arrow on image ' $A$ ' shows the shadow of the wire Ryc. 4. Obserwacja 6-miesięczna po wszczepieniu stentu uwalniającego ewerolimus - Promus Element, do żylnego pomostu wszytego do prawej tętnicy wieńcowej w celu leczenia restenozy w stencie metalowym Duet. Optyczna tomografia koherentna uwidacznia dwie, zasadniczo koncentryczne (A-D) lub ekscentryczne (E) warstwy tkanki restenotycznej, które wyraźnie różnią się między sobą. Dodatkowo można dostrzec różnice pomiędzy neointimą pokrywająca pierwszy stent (metalowy) i drugi stent (uwalniający ewerolimus) (strzatki) (F). Strzatka na obrazie 'A' wskazuje na cień prowadnika 


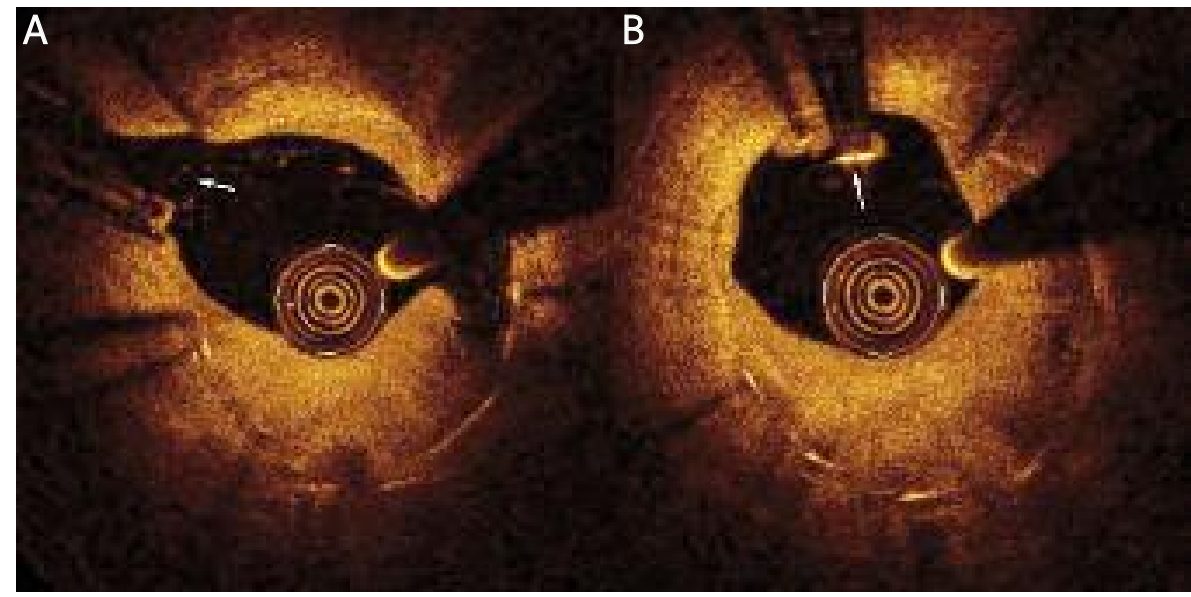

Fig. 5. Five-year follow-up after implantation of Paclitaxel-eluting stent Taxus into the right coronary artery. Optical coherence tomography reveals extremely eccentric homogeneous in-stent restenosis opposite the take-off of the side branch (arrow) (A), with one uncovered strut (arrow) close to the ostium of the side branch (B) Ryc. 5. Obserwacja 5-letnia po wszczepieniu stentu uwalniającego ewerolimus - Taxus, do prawej tętnicy wieńcowej. Optyczna tomografia koherentna uwidacznia bardzo ekscentryczna, homogenna tkankę restenotyczna naprzeciw odejścia gatęzi bocznej (strzatka) (A). Widoczna jest jedna rozpórka stentu zlokalizowana blisko ujścia gatęzi bocznej, która nie jest pokryta przez neointimę (B)

\section{References}

1. Gonzalo N, Serruys PW, Okamura T, et al. Optical coherence tomography patterns of stent restenosis. Am Heart J 2009; 158: 284-293.

2. Suzuki N, Angiolillo DJ, Monteiro C, et al. Variable histological and ultrasonic characteristics of restenosis after drug-eluting stents. Int J Cardiol 2008; 130: 444-448. 